\title{
Analysis of the Effect of Quality of Work Life, Job Satisfaction, and Employee Performance in Network and Telecommunications Service Companies
}

\author{
Hady Siti Hadijah $^{1(*)}$, Budi Santoso ${ }^{1}$, Adman ${ }^{1}$, Alit Sarino ${ }^{1}$ \\ ${ }^{1}$ Program Studi Pendidikan Manajemen Perkantoran, Fakultas Pendidikan Ekonomi dan Bisnis, Universitas Pendidikan \\ Indonesia \\ *Corresponding author. Email: hady@upi.edu
}

\begin{abstract}
The purpose of this study is to analyze how the quality of work life and job satisfaction can effectively improve employee performance. The research method used is descriptive and associative methods. Data were collected through questionnaires using a Likert scale model, then analyzed using multiple regression. The unit of analysis of this research is 70 employees at a network and telecommunications service company in Bandung. The results showed that the network and telecommunications service company had a good quality of work life, a high level of employee job satisfaction, and a high level of employee performance as well. The partial test results show that Quality of Work Life has an influence on Job Satisfaction, Quality of Work Life has an influence on Employee Performance, and Job Satisfaction has no effect on Employee Performance. Keywords: Quality of work life, job satisfaction and employee performance
\end{abstract}

\section{INTRODUCTION}

The role of services and telecommunications in the era of globalization is increasing in accordance with the development and economic, social and cultural growth. This increased growth is in line with the community's need for this facility for both business, government and family interests. With the start of the era of free trade, the impact of free competition between similar companies on a national and international scale. Many new competitors have emerged in the field of network and telecommunications services that have competed to win business competition.

The occurrence of this competition can affect the continuity of the company in carrying out its business activities. One way to improve the quality and quantity of services is to improve the quality of human resources owned by the company. Companies are required to obtain, develop and maintain quality Human Resources in order to compete in business competition. Human Resources as the driving force of an organization is heavily influenced by the participants, and the role of its functions is very supportive for the success of the organization.

Human resources, in this case employees, are valuable assets of the company that must be managed well by the company in order to make optimal contributions. One of the things that must be a major concern of the company is the quality of the work lives of its employees, because employees who do not feel comfortable, are less valued, cannot develop all their potential, make employees unable to focus and concentrate fully on their work. Another thing to note is that employee job satisfaction is thought to improve employee performance. With high employee performance will produce high productivity as well. Job satisfaction is one component that supports the achievement of productivity. Robbins (2017) defines job satisfaction as a general attitude of individual attitudes towards work in order to achieve good employee performance.

\section{LITERATURE STUDY AND HYPOTHESIS}

\section{Quality of work life}

Quality of Work Life can be interpreted into two views, namely: the first view states that Quality of Work Life is a set of conditions and practices of organizational goals (Cascio, 2006),. The second view states that Quality of Work Life is the perceptions of employees such as employees feel safe, relatively feel satisfied and get the opportunity to grow and develop. Arnold and Feldman (1986) in Anggraeni (2009) in Loss et al (2017), said that the quality of work life aims to create organizational conditions that can help employee development for learning. This is evidenced by the role of the organization as a controller of how employees do their jobs and provide opportunities to do interesting and meaningful work for employees so as to cause personal satisfaction that can affect organizational effectiveness. Quailty of Work Life is a management system approach to coordinate / connect 
the potential of Human Resources, where the quality of work life in an organization as a leadership effort to meet the needs of members and organizations simultaneously and continuously (Lumbantoruan: 2015).

All employees want their dignity to be recognized, meaning that management must pay serious attention to the various sociopsychological aspects of the work and not only to the material aspects in various forms of rewards to employee performance. To achieve this goal, improving the quality of life of workers must involve employees from various aspects of the approach. In addition, work improvement needs to be done with the help of a conducive work environment and effective communication patterns. While improving the quality of work life can be done in the form of an employee communication system, employee involvement, enrichment of the work, and a conducive work environment. (Irawati: 2015).

Work Quality Quality Standards according to Davis translated by Dharma (1992: 476) in Irawati (2015) The standard of quality of work life is: 1). Fair, fair and fair treatment of employees; 2). There are opportunities for employees to use their abilities to the full and opportunities to manifest themselves, namely to make them feel able to make it happen; 3). Open and mutual communication between individuals in the organization; 4). Every employee plays an active role and they have the opportunity to make important decisions that involve their work; 5). Adequate and fair compensation; 6). Safe and healthy environment.

Based on the explanation above, for this study indicators were used in the application of Quality of Work Life Cascio (2006), namely: Employee Participation, Conflict Resolution, Communication., Occupational Health, Work Safety, Work Safety, Compensation decent, as well as Career Development.

\section{Job Satisfaction}

The level of satisfaction of each individual is always different according to the values that apply to him. Hasibuan in Cahya Kusuma W (2015) states job satisfaction as an emotional attitude that is fun and loves the work he does. Then Mangkunegara in Cahya Kusuma W (2015) states that job satisfaction is a feeling from employees who are related to their work or to their condition. it can be concluded that job satisfaction is the attitude of employees towards workrelated matters that reflect the results of work done. According to Hasibuan (2013) Job Satisfaction at work is job satisfaction enjoyed at work by obtaining compliments for work, placement, treatment, equipment, and a good working environment. In addition, according to Luthan (2006) Job satisfaction is "the result of employees' perceptions of how well their work provides what is considered important". Job Satisfaction according to Robbins (2017) is a positive feeling about work, which results from an evaluation of its characteristics. Then Handoko (2014) states that job satisfaction is a pleasant or unpleasant emotional state with the names of the employees looking at their work. Job satisfaction is "the result of employees' perceptions of how well their work provides what is considered important. According to Rivai in Setiyadi and Sri (2016) the notion of job satisfaction is an evaluation describing someone's feelings of being happy or unhappy, satisfied or dissatisfied at work. In addition, the notion of job satisfaction according to the several definitions put forward by the experts mentioned above, it can be concluded that job satisfaction is the level of a person's feelings towards work by considering and assessing all aspects of their work, so that arises in him a feeling of pleasure or not happy about work situations and coworkers.

Three satisfaction theories that are commonly known according to Wexley (2005) are as follows: Discrepancy Theory (theory of discrepancy), Equity Theory (justice theory), and Two Factor Theory (two factor theory). The following theories are put forward:

1. Discrepancy Theory (discrepancy theory). According to Locke in Wexley (2005 :), satisfaction or dissatisfaction with a number of aspects of work depends on the difference (discrepancy) between what has been obtained with what is desired.

2. Equity Theory (theory of justice). The theory of justice detailing the conditions under which a worker will consider fair and reasonable incentives and benefits in his work.

3. Two Factor Theory (two factor theory). The twofactor work attitude theory states that job satisfaction is qualitatively different from job dissatisfaction, Herzberg Mausner, and Snyderman in Wexley (2005: 137).

According to Rivai in Setiyadi and Sri (2016) that the factors that are usually used to measure an employee's job satisfaction consist of job content, the appearance of actual work tasks and as control of work, supervision, organization and management, opportunities for advancement, salary and other financial benefits such as incentives, coworkers and working conditions. Luthan (2006) in his book states that there are several indicators of Job Satisfaction, these indicators namely Loving work and feeling satisfied with work. Based on the explanation above, the indicators used in this research are liking work and positive attitude (proud) towards work.

\section{Employee Performance}

Performance according to the Big Indonesian Dictionary is something to be achieved, achievement shown and work ability. Performance is used by management to conduct periodic assessments of the operational effectiveness of an organization and employees based on predetermined goals, standards and 
criteria. With performance, the organization and management can find out how far the success and failure of its employees in carrying out the mandate received. Then, Mathis and Jackson (2006) stated that Performance is basically what employees do or don't do in carrying out their work. Afrizall et al (2012) states that performance is a condition that must be known and informed to certain parties to determine the level of achievement of an agency's results related to the vision carried out by an organization and to know the positive and negative impacts of an operational policy taken. With information about the performance of a government agency, the necessary actions can be taken such as corrections to policies, aligning the main activities, and the main tasks of the agency, materials for planning, determining the level of success of the agency to decide on an action, and others. Performance is defined as a contribution to an organization's final output in relation to resources spent and must be measured by qualitative and quantitative indicators. Then the development of the instrument was carried out to assess work perceptions of their own performance in relation to items such as output, achievement of goals, meeting deadlines, use of working hours and sick leave.

One way to look at company development is by looking at the results of performance research. The targets that are the object of performance appraisal are the skills, the ability of employees to carry out a job or task that is evaluated periodically. From the results of the assessment can be seen that the company's performance is reflected by employee performance or in other words, performance is the result of concrete work that can be observed and measured. A company evaluates performance based on two main reasons: (1) the manager conducts an objective evaluation of past employee performance that is used to make decisions in the HR field in the future; and (2) managers need tools that enable them to help their employees improve performance, plan jobs, develop skills and skills for career improvement and strengthen the quality of relationships between managers concerned with their employees.

Elmuti and Kathawala in Irawati (2015) stated that performance can be measured through five indicators: 1). Quality, i.e. the results of activities carried out near perfect, in the sense of adjusting some ideal ways of performing activities in meeting the expected goals of an activity; 2). Quantity, i.e. the amount or target produced is expressed in terms of units of the number of activity cycles completed; 3 ). Knowledge and skills, namely knowledge and skills possessed by employees of an organization; 4). Timeliness, i.e. activities completed at the desired initial time are seen from the point of view of coordinating the outputs and maximizing the time available for other activities; 5). Communication, namely relationships or interactions with fellow colleagues in the organization. In this study, indicators used to measure employee performance are Quality, Quantity, Timeliness, Attendance, Ability to Work Together

\section{The Effect of Quality of Work Life on Job Satisfaction}

Hasanmoradi's research (2011) in Christiyadi et al (2014), shows that teachers from both Public and NonPublic Schools are in a relatively unfavorable quality of life, but they enjoy a high level of job satisfaction. There is a positive and significant relationship between work quality and work satisfaction factors. There are significant differences in the level of quality of work life and job satisfaction between public school teachers and non-public schools.

Thus, the first research hypothesis can be formulated as follows:

H1: Quality of Work Life has an effect on job satisfaction

\section{The Effect of Quality of Work Life on Employee Performance}

Research conducted by Husnawati (2006) in Christiyadi et al (2014), shows that the quality of work life, commitment and job satisfaction have a direct and indirect effect on performance. Research Majumdar et al. (2012) in Christiyadi et al (2014), investigated the relationship between quality of work life and its effect on performance. The determinants of QWL variables include organizational culture, work relationships, that is, relationships with superiors and among peers, training and facility development, reward systems, benefits, job security, autonomy, variations in work schedules. Job Performance Parameters include both financial and non-financial dimensions such as current ratio, return on capital (ROCE), return on net worth / equity (ROE), net profit margin and return on asset (ROA) ratios while non-financial indicators indicate individual performance standards. The results of the analysis of five public and private companies under the Indian Service Industry, only one company showed a low correlation between quality of work life and performance.

Thus, the second research hypothesis can be formulated as follows:

H2: Quality of Work Life has an effects on Employee Performance

\section{The Effect of Job Satisfaction on Employee Performance}

Research by Hira and Waqas (2012) in Christiyadi et al (2014), conducted a study to explain the nature of the relationship between job satisfaction and job performance among mid-level banking sector employees in Pakistan with the economic background of Pakistan facing the economic crisis of the past 30 years and the banking sector showed instability since 2005. The conclusion of the research is that there is a 
positive relationship between job satisfaction and performance.

Thus, the third research hypothesis can be formulated as follows:

H3: Job satisfaction has an affects to employee performance

Based on the description of the causal relationship between the variables above, the research paradigm that shows that Transformational Leadership can affect Bank Performance directly or through Intellectual Capital can be seen in Figure 1.

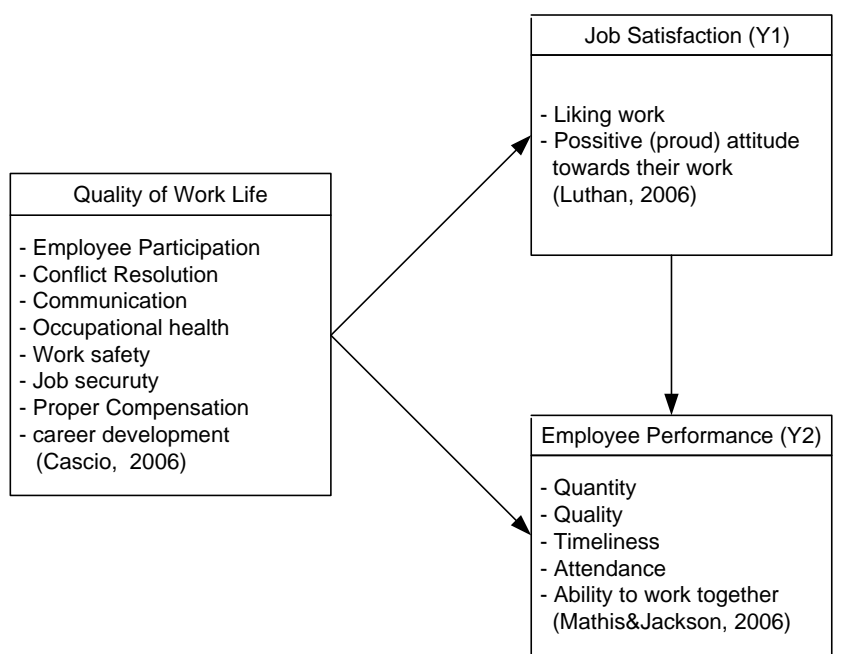

Figure 1. Research Paradigm

\section{METHOD}

\section{Sample and Procedure}

This research uses descriptive and associative methods. This research is descriptive verification. The population is all employees of a multinational company from China engaged in network and telecommunications equipment and services that have a representative office named PT. Huawei Tech Investment (HTI). HTI established its main office in Jakarta. The sample size used in this study were employees of PT. Huawei Tech Investment Bandung, amounting to 70 people who are also the respondents. Researchers visited the employees of PT. Huawei Tech Investment (HTI) which has been registered to fill in a closed questionnaire In addition, we also conduct open interviews with several office leaders to dig up some information related to the variables we examined.

\section{Measurement}

The Quality of Work Life variable is measured through 8 statement items with a Likert scale. These items measure the level of Quality of Work Life of employees in terms of employee participation, conflict resolution, communication, occupational health, work safety, job security, proper compensation, and career development.
Variable Capital Work Satisfaction is measured through 2 statement items with a Likert scale. These items measure the level of employee job satisfaction in terms of liking work and a positive (proud) attitude towards their work.

Employee Performance Variables are measured through 5 item statements with a Likert scale. These items measure the performance of the bank branch office in terms of quality, quantity, timeliness, attendance, and the ability to work together

\section{RESULTS AND DISCUSSION Descriptive Analysis}

Based on the results of the distribution of questionnaires to 70 respondents who have been done to the employees of PT. Huawei Tech Investment Bandung, on average, respondents are more dominated by age $26-30$ years with a percentage of $45.7 \%$. Based on the sex of the respondent in PT. Huawei Tech Investment Bandung is mostly male compared to female employees with a percentage of $65.7 \%$. Based on the latest education of respondents at PT. Huawei Tech Investment Bandung, most of the employees who work have D3 education with a percentage of $41.4 \%$. And the length of time worked by respondents at PT. Huawei Tech Investment Bandung has a long working time working for $<5$ years the percentage is $51.4 \%$.

To analyze respondents' responses, the respondent's answer will be weighted by multiplying the number of respondents who answered by the likert scale value of the answer. After that the value of the answer is compared with the standard weight value to find out its performance. This standard weight value is divided into three (3) ranges of assessment which are good, not good and not good.

Descriptive analysis in this study uses the mean value to give a comprehensive picture of each variable, where the categories of each variable refer to Table 1

Table 1. Variable Categorycal

\begin{aligned} & \hline Interval \multicolumn{1}{c}{ category } \\ & \hline $\mathbf{7 0}-\mathbf{1 1 7}$ Poor/Low \\ & $\mathbf{1 1 8}-\mathbf{1 6 5}$ Less Good/Less high \\ & $\mathbf{1 6 6}-\mathbf{2 1 3}$ Good/High \\ & \hline\end{aligned}

\begin{tabular}{lc}
\hline \multicolumn{2}{c}{ Tabel 2. Descriptive Statistics } \\
\hline Variable & Mean \\
\hline Quality of Work Life & 178.5 \\
Job Satisfaction & 179.5 \\
Employee Performance & 180 \\
\hline \multicolumn{1}{c}{ Quality of Work Life is measured using 8}
\end{tabular}

Quality of Work Life is measured using 8 indicators. Based on the results of the responses of 70 respondents obtained an average score of 178.5 (Good category), which means the level of quality of work life of employees at PT. Huawei Tech Investment Bandung is well perceived by employees. Job satisfaction is measured using 2 indicators. The average score of 
179.5 (Good category), which means the level of job satisfaction of employees at PT. Huawei Tech Investment Bandung is highly perceived by employees. Employee performance is measured using 5 indicators. The average score of 180 (good category), which means the performance of employees at PT. Huawei Tech Investment Bandung is highly perceived by employees. Based on the scores obtained by each indicator from the variable Quality of Work Life shows that the indicator that has the lowest score is conflict resolution. This means that conflict resolution in the company receives less attention from management. As for the indicators that have the highest RH. This means that work safety is an indicator that best reflects the Quality of Work Life. Thus the company should increase attention to conflict resolution so that satisfaction and performance increase. In addition, it is also recommended for companies to improve their work safety programs, because the Quality of Work Life is largely determined by the work safety program. By paying great attention to conflict resolution and improving work safety programs means that it has improved the Quality of Work Life which has a positive impact on Satisfaction and Performance

Regression Analysis and Hypothesis Testing

Test of the Effect of Quality of Work Life (X) on Job Satisfaction (Y1)

Table 3. Regression Coeffisients Sub Structure I Coefficients $^{\mathbf{a}}$

\begin{tabular}{|c|c|c|c|c|c|}
\hline \multirow[t]{2}{*}{ Model } & \multicolumn{2}{|c|}{$\begin{array}{c}\text { Unstandardi } \\
\text { zed } \\
\text { Coefficients }\end{array}$} & $\begin{array}{c}\text { Standardi } \\
\text { zed } \\
\text { Coefficien } \\
\text { ts }\end{array}$ & $\mathbf{t}$ & $\begin{array}{c}\text { Sig } \\
\text {. }\end{array}$ \\
\hline & B & $\begin{array}{l}\text { Std. } \\
\text { Erro } \\
\text { r }\end{array}$ & Beta & & \\
\hline $\begin{array}{l}1 \text { (Consta } \\
\text { nt) }\end{array}$ & 1.103 & .832 & & $\begin{array}{r}1.32 \\
5\end{array}$ & $\begin{array}{l}.19 \\
0\end{array}$ \\
\hline$X$ & .180 & .054 & .373 & $\begin{array}{r}3.31 \\
8\end{array}$ & $\begin{array}{r}.00 \\
1\end{array}$ \\
\hline
\end{tabular}

a. Dependent Variable: Y1

In the Coeffecients table (Table 3) we can see the tcount is 3,318 . While the value of ttable is the value of t-student distribution at the real level $(\alpha)$ of $5 \%$ with a free degree of 23 that is 1.67 (1 party test)

Based on Table 3 above, it can be seen that tcount> ttable, meaning that Quality of Work Life (X) has a significant effect on Job Satisfaction (Y1). If there is only a slight change in the variable Quality of Work Life $(X)$, there will immediately be a significant change in the variable Job Satisfaction (Y1)

Test of the Effect of Quality of Work Life (X) and Job Satisfaction (Y1) on Employee Performance (Y2)
The following will be tested the effect of Quality of Work Life (X) and Job Satisfaction (Y1) on Employee Performance (Y2).

Table 4. Regression Coeffisients Sub Structure 2 Coefficients $^{\mathrm{a}}$

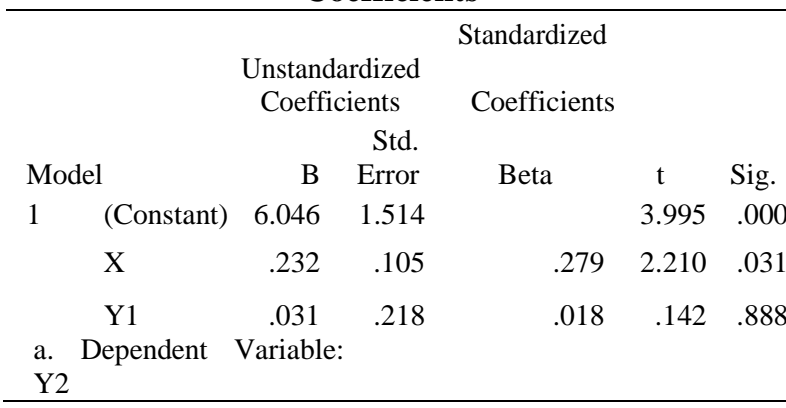

Test of the Effect of Quality of Work Life (X) on Employee Performance (Y2)

Based on Table 4 above it can be seen that the value of tcount $=2.210$ is greater than ttable $=1.67$; meaning that Quality of Work Life has a significant effect on Employee Performance (Y2). If there is only a slight change in the variable Quality of Work Life $(\mathrm{X})$, there will immediately be a significant change in the variable Employee Performance (Y2).

\section{Test of the Effect of Job Satisfaction (Y1) on Employee} Performance (Y2)

Based on Table 4 above it can be seen that the value of tcount $=0.142$ is smaller than ttable $=1.67$; it means that Quality of Work Life has no significant effect on Employee Performance (Y2). If there is only a slight change in the variable Job Satisfaction (X), there will not immediately be a significant change in the Employee Performance variable (Y2). This can occur because high satisfaction may not necessarily affect performance. For example, leave and work hours can increase satisfaction but will reduce performance.

The magnitude of the effect of work quality and job satisfaction on Employee Performance is at 8,20\%. This value is obtained from the coefficient of determination (R2) of the regression equation shown in the following Summary Model Table (Table 5):

Table 5. Summary ${ }^{b}$ Model

\begin{tabular}{|c|r|r|r|r|l|}
\hline & & & $\begin{array}{c}\text { Adjuste } \\
\mathrm{d} \mathrm{R}\end{array}$ & $\begin{array}{c}\text { Std. Error of } \\
\text { the }\end{array}$ & \\
$\begin{array}{c}\text { Mode } \\
1\end{array}$ & $\mathrm{R}$ & $\mathrm{R}$ Square & Square & $\begin{array}{c}\text { Estimat } \\
\mathrm{e}\end{array}$ & $\begin{array}{c}\text { Watso } \\
\mathrm{n}\end{array}$ \\
\hline & .286 & .08 & & & \\
1 & $\mathrm{a}$ & 2 & .054 & 2.26291 & 2.143 \\
\hline
\end{tabular}

a. Predictors: (Constant),

$\mathrm{Y} 1, \mathrm{X}$

b. Dependent Variable: Y2 


\section{CONCLUSION}

Based on the results of the hypothesis test it was concluded that the Quality of Work Life at PT Huawei Tech Investment Bandung is in good condition, then Job Satisfaction at PT Huawei Tech Investment Bandung is in high condition and the Performance of Employees of PT Huawei Tech Investment Bandung is in high condition. Quality of Work Life has a positive and significant impact on Job Satisfaction. This shows that the level of employee satisfaction depends on the quality of the work life of employees. Quality of Work Life also has a positive and significant impact on the Performance of Employees at PT Huawei Tech Investment Bandung. This shows that the high and low performance of employees depends on the good or bad poor quality of work life of employees as well. The Job Satisfaction does not affect the Performance of Employees of PT Huawei Tech Investment Bandung. This shows that the level of employee performance does not depend on the level of employee satisfaction

\section{ACKNOWLEDGMENTS}

We thank the leaders of PT Huawei Tech Investment Bandung, especially employees who are willing to be the object of this research. I would also like to express my gratitude to Program Studi Pendidikan manjemen Perkantoran, Fakultas Pendidikan Ekonomi dan Bisnis, Universitas Pendidikan Indonesia, and the Vice Chancellor for Research and Partnership Research at Universitas Pendidikan Indonesia for facilitating the authors to publish research results.

\section{REFERENCES}

Afrizall dkk. 2012. Pengaruh kualitas kehidupan kerja (quality of work life), dan kompensasi terhadap loyalitas serta dampaknya pada kinerja karyawan pt. Bank aceh cabang bener meriah. Jurnal Ilmu Manajemen Pascasarjana Universitas Syiah Kuala, Volume 1, No. 1, Agustus 2012

Cahya Kusuma W, Putri dkk. 2015. Pengaruh stres kerja dan kualitas kehidupan kerja terhadap kepuasan kerja dan kinerja karyawan (Studi pada karyawan non medis RSUD Ibnu Sina Gresik). Jurnal Administrasi Bisnis (JAB)| Vol. 1 No. 1 Januari 2015

Cascio, W. F. (2006). Managing Human Resources: Productivity, Quality of Work-Life, profits. (2nd ed.). New York: McGraw-Hill

Christiadi, Antoni Y dkk. 2014. Pengaruh Kualitas Kehidupan Kerja Dan Motivasi Terhadap Kinerja Pegawai Melalui Kepuasan Kerja (Studi pada Universitas Palangka Raya). JSM (Jurnal Sains Manajemen) Program Magister Sains
Manajemen UNPAR, Volume III, Nomor 2, September 2014

Hani, T. Handoko. 2014. Manajemen Personalia dan Sumber Daya Manusia. BPFE-Yogyakarta

Hasibuan, Malayu S.P. 2005. Manajemen Sumber Daya Manusia. Jakarta : PT. Bumi Aksara

Irawati, S Anugrahini. 2015. Pengaruh kualitas kehidupan kerja terhadap kinerja pegawai dinas perindustrian dan dan perdagangan kabupaten sampang. Jurnal Neo-bis Volume 9, No. 2, Des 2015

Lumbantoruan, Erik Robson. 2015. Pengaruh kualitas kehidupan kerja, kepuasan kerja dan komitmen karyawan terhadap kinerja karyawan terhadap kinerja karyawan dan prilaku kewargaan sebagai variabel intervening (studi pada pt. Perindustrian dan perdagangan crumb rubber pekanbaru). Jom fekon Vol. 2 No. 1 Februari 2015 Wipedia Indonesia

Luthans, Fred. 2006. Perilaku Organisasi. Edisi 10. Yogyakarta: Andi

Mathis, Robert L dan Jackson. 2006. Manajemen Sumber Daya Manusia. Jakarta. Salemba Empat

Robbins SP, dan Judge. 2017. Perilaku Organisasi. Salemba Empat, Jakarta

Rugian, Melina S, dkk. 2017. Pengaruh disiplin kerja, pelatihan, kualitas kehidupan kerja dan konflik pekerjaan-keluarga terhadap kinerja karyawan (studi kasus pada pt bank btpn tbk cabang utama manado). Jurnal EMBA Vol.5 No.2 Juni 2017

Setiyadi, Yusuf W dan Sri. 2016. Pengaruh kualitas kehidupan kerja terhadap kinerja karyawan dengan kepuasan kerja sebagai variabel intervening. Management Analysis Journal 5 (4) (2016)

Wexley, K.N and Yuki, G.A. 2005. Prilaku Organisasi dan Psikologi Personalia, Jakarta: Rineka Cipta 